\title{
Activism, scientists and sociobiology
}

\section{A scientific movement honed by capitalists, Marxists - and the Vietnam War.}

\author{
Defenders of the Truth: The Battle \\ for Science in the Sociobiology \\ Debate and Beyond \\ by Ullica Segerstråle \\ Oxford University Press: 2000. 493 pp. \\ $\mathfrak{2} 20, \$ 35$
}

\section{David L. Hull}

For more than 20 years Ullica Segerstråle has been charting the course of sociobiology, beginning with E. O. Wilson's Sociobiology (1975) and Richard Dawkins' The Selfish Gene (1976) through to the present-day 'science wars' and evolutionary psychology. Although she is interested in broad sociological and philosophical trends, her exposition here consists mainly in discussions of individual people, their views and their interrelations.

The chief advocates of sociobiology in the United States whom Segerstråle considers are E. O. Wilson, Robert Trivers and Bernard Davis; the chief opponents are Richard Lewontin, Stephen Jay Gould, Richard Levins, Jon Beckwith and Stephen Chorover. In the United Kingdom she emphasizes the work of Richard Dawkins, W. D. Hamilton and John Maynard Smith; Steven Rose and Patrick Bateson are the chief critics. In the
United States Wilson emerged as the father of sociobiology whereas in Britain this role devolved on Richard Dawkins, although quite understandably he preferred to call this movement by a name other than the one coopted by Wilson.

Segerstråle interviewed all the major figures in these disputes and many of the minor figures too. She also attended meetings, both formal and informal, and read the vast literature that sociobiology generated. Her goal was to understand the factors that influenced the course of this scientific movement.

The controversial thread that runs through her narratives is the nature of science. Science functions within a culture. So, do the various sociocultural contexts influence science? Do capitalist societies necessarily produce capitalist science? According to the traditional 'internalist' view of science, scientists make up their minds on scientific issues primarily through reason, argument and evidence. Other factors may be involved, but they should be weeded out.

Just as sociobiology was emerging, a quite different view of science was becoming influential. According to this view, scientists make their decisions in large measure influenced

by broader social contexts, such as those of economics and class structure.

More specifically, Segerstråle attempts to discover exactly what the views of the biologists she studied were and why they held them. On what basis do the sociobiologists as well as their opponents evaluate sociobiology? For example, the versions of evolutionary theory that sociobiologists extended to behaviour and social structure tended to be very individualistic and competitive. Sociobiologists tend to think that selection occurs only at the lowest levels of organization, a position their critics attribute to their economic leanings: the individual is paramount in free-enterprise economic systems. The Marxist opponents of sociobiology tend to think that selection can occur at higher levels of organization, including groups. In Marxism, groups are more important than individuals. Capitalists view nature as competitive, whereas these Marxist critics tend to view it as being much more cooperative.

As Segerstråle notes, one problem with posing the issue in the way she does is that sociobiology's opponents lived in exactly the same array of societies and subsocieties as their opponents. During their formative years, nearly all of the protagonists in this controversy were raised in competitive, sexist and racist societies. Why did some of them internalize these features of their societies whereas others did not? Was Wilson really a racist, or did his work just exhibit tacit racism? Segerstråle makes no mention of anyone calling Lewontin a racist. How did he avoid picking up this feature of his society?

According to externalists, political leanings influence the scientific views that scientists hold. Lewontin, Levins and Gould are Marxists; hence, their views on evolution should be influenced by their Marxism. But John Maynard Smith was a more active Marxist than any of these people. Yet he held and still holds views on evolution that are at variance with those of other Marxists and in support of such capitalist running dogs as Wilson and Dawkins. If both internal and external factors affect the course of science, these influences are extremely complicated and at times they conflict.

Segerstråle does not just relate what she has read or what her respondents have told her; she evaluates it and passes judgement on it. Looking back over the past quarter-century, she considers one of the gratifying developments to have been that we have a "relative vindication of the sociobiologists unfairly accused at the beginning of the controversy".

To complicate matters further, Segerstråle was engaged in the same sort of activity as her

Leon Golub: Echoes of the Realby Jon Bird (Reaktion Books, $\mathfrak{E 1 7 . 9 5 , \$ 2 9 ; ~ p b k ) ~ a s s e s s e s ~ t h e ~}$ history painter's life and work. gesture over the Vietnam War, a "symbolic icon of nationhood as a visceral and bloody stain". 
subjects. She was a scientist studying scientists, a meta-scientist if you will. She had to make decisions about what she thought she was doing. The fact that she spends a lot of time explaining the relevant science implies that she thinks it matters. If it can influence her, it can influence other scientists as well. This problem confronts all students of science. How we study science implies something about what we take science to be.

As Segerstråle sees it, the significant difference between Wilson and Lewontin was in their attitude towards science. Wilson was willing to take chances, to come up with new ideas and to pursue them even if they seemed implausible or overly ambitious. He admits that his early efforts to biologize all of the social sciences, not to mention the humanities, might seem too simplistic. But he says the beginnings of general theories come out of such oversimplifications. Lewontin, in contrast, possibly because he thinks that such things as social class can influence science, holds a hard-nosed attitude to science - new theories must be clearly formulated and backed up with significant amounts of data.

Accurate though her explanation of the differences between Wilson and Lewontin might be, Segerstråle pays insufficient attention to one crucial aspect of the sociopolitical context of the time - the Vietnam War. Many Americans felt helpless during this time. They were faced with a lot of problems, not the least of which was a cruel, stupid war about which there was so little they could do. They could sign petitions, march in protest and burn draft cards, but that was about it. Early in her discussion, Segerstråle remarks that the sociobiology controversy was not between the left and right. "The actual dividing line went, rather, between a particular type of New Left activist on the one hand and traditional liberals and democrats on the other." The key term is "activist". The battle waged against sociobiology was part of this activism.

I must also mention the most famous incident of all. In 1978, at a meeting of the American Association for the Advancement of Science, both Segerstråle and I attended a session on sociobiology at which Wilson was to present a paper. As he began his presentation, a dozen or so members of the International Committee Against Racism marched up onto the stage, chanting: "Racist Wilson you can't hide, we charge you with genocide!" A woman then poured water over Wilson's head. How much water is a matter of conjecture. Usually we are told it was a pitcher of water. Segerstråle remembers a jug. I am sure that it was a small paper cup. One bit of evidence that supports my memory of the incident is that Wilson was able to mop up the water with a single handkerchief. Such are the problems of eye-witness reports.

David L. Hull is in the Department of Philosophy, Northwestern University, Evanston, Illinois 60608, USA.

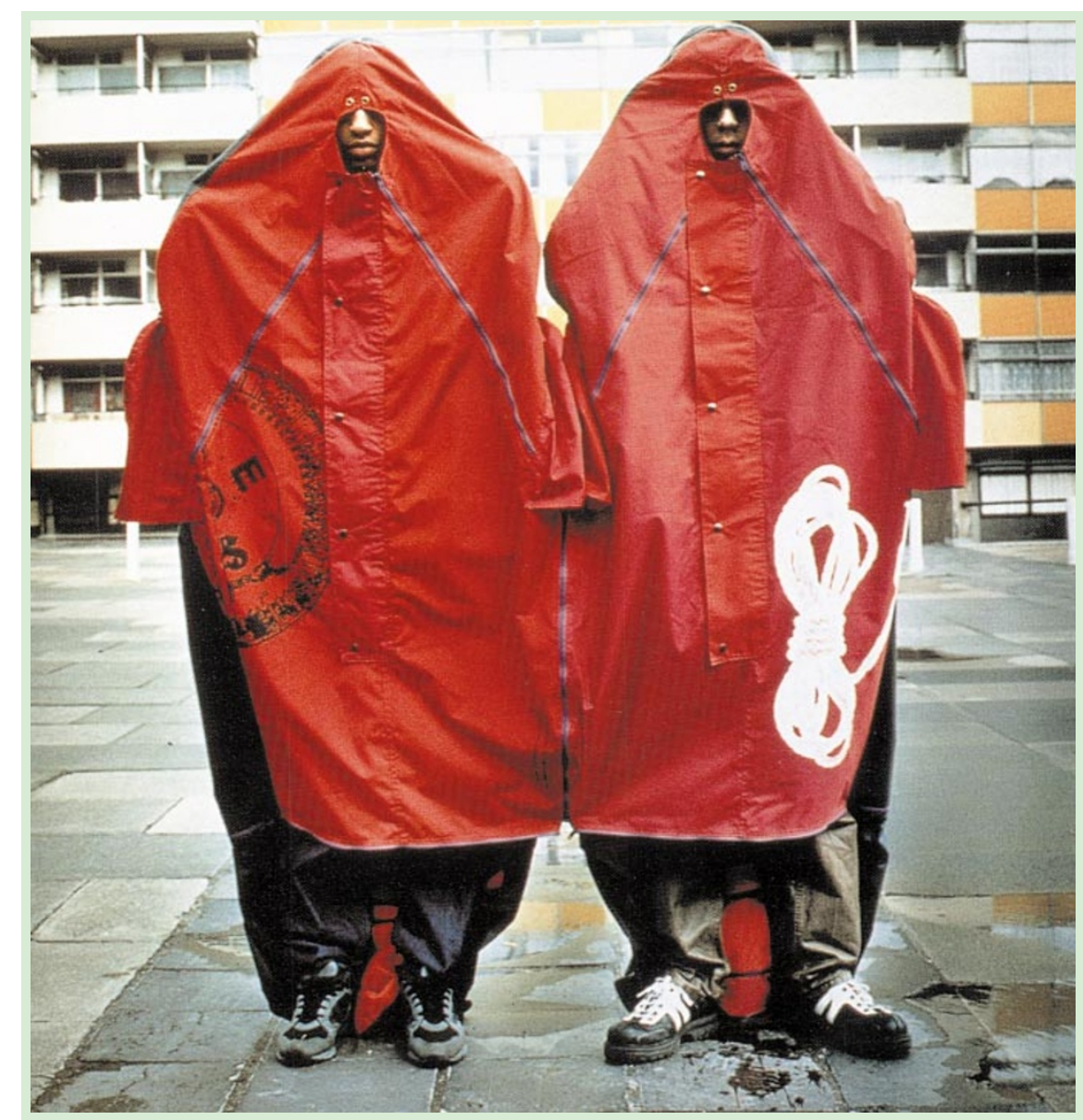

The climate of fashion

Artist Lucy Orta's Refuge Wear. Collective Survival Sac - 2 Persons. With Transformable Rucksack. From a brief pictorial overview, Art $\nleftarrow$ Fashion by Florence Müller (Thames \& Hudson,

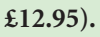

\section{Dowsing the human volcano}

Something New Under the Sun: An Environmental History of the Twentieth-Century World by J. R. McNeill

Allen Lane/W. W. Norton: 2000. 421/448 pp.

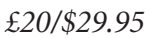

\section{Paul Crutzen}

Looking back at mankind's impact on the environment during the twentieth century, with J. R. McNeill, professor of history at Georgetown University, as a guide, one is both impressed and depressed. To take a few examples from this highly informative book: the world population grew by a factor of four to around 6,000 million; the urban population increased 13-fold; industrial output increased 40 times and energy use 16 times. In the twentieth century, according to McNeill's estimate, humans used ten times more energy than during the whole of the rest of the millennium. Water use increased by a factor of seven, and the methaneproducing cattle population paralleled the increase in the human population; on average, one cow per family supplies humans with dairy products and meat. The fish catch grew 35 times; and emissions of carbon dioxide and sulphur dioxide grew by a factor of more than ten.

The Earth's carbon, nitrogen and sulphur cycles are now strongly perturbed by agricultural and industrial activities. The global release of sulphur on the continents as a result of the burning of coal and oil - the "human volcano" - is an order of magnitude larger than all natural inputs combined. The supply of nitrogen to the environment from fertilizer application and from fossil-fuel burning is of a similar magnitude to total global biological nitrogen fixation.

The environmental impacts on the atmosphere are well known: unhealthy air to breathe in industrial cities, acid rain, photochemical smog, and increases in the greenhouse gases carbon dioxide, nitrous oxide 